Indonesian Journal of Biotechnology, December 2015

Vol. 20, No. 2, pp.167-173

\title{
Identification of antibiotic producing endophytic microbe isolates from a national park in Java island
}

\author{
Sri Yuwantiningsih ${ }^{1 *}$, Sebastian Margino ${ }^{2}$, Subagus Wahyuono ${ }^{3}$
}

\begin{abstract}
${ }^{1}$ Biotechnology, Study Program, The Graduate School, Universitas Gadjah Mada, Yogyakarta, Indonesia ${ }^{2}$ Faculty of Agriculture, Universitas Gadjah Mada, Yogyakarta, Indonesia

${ }^{3}$ Faculty of Pharmacy, Universitas Gadjah Mada, Yogyakarta, Indonesia
\end{abstract}

\begin{abstract}
Endophytic microbes are potential sources of antibiotics. Some numbers of endophytic bacteria were isolated from plants in Ujung Kulon, Kaliurang, Meru Betiri and Baluran National Park, Bogor Botanical Garden, and Nusakambangan forest, Indonesia. Previous studies have been conducted to examine and obtain endophytic bacteria isolates from the selected plants, which resulted in three selected isolates, namely OOH-1, STG-1, and CMB-2. This research was conducted to determine the molecular identity of OOH-1 and STG-1 isolates, as well as to identify antibiotic compounds produced by STG-1 isolate. Molecular identification of selected isolates was based on $16 \mathrm{~S}$ rRNA gene analysis and amplified using primers $27 \mathrm{~F}$ and $1492 \mathrm{R}$. A phylogeny tree was then constructed by comparing the resulting sequences with data from Gene Bank using the BLAST-N program. The identification showed that STG-1 isolate had a 99\% similarity with Pseudomonas brenneri strain SFML 97-391, and $\mathrm{OOH}-1$ isolate had a $99 \%$ similarity with Enterobacter xiangfangensis. Identification of antibiotic compounds was done by purification and separation of the compounds. Antibiotic activity was also examined based on Lethal Concentration $\left(\mathrm{LC}_{50}\right)$ on Fusarium oxysporum with a $\mathrm{LC}_{50}$ of $0.01-0.02 \%$ against Fusarium oxysporum.
\end{abstract}

Keywords: antibiotic, endophytic microbes, molecular identification

\section{Introduction}

Within the last 20 years, the search for new types of antibiotics has been increasing, with the growth reaching 200\% from 1979 to 2000 (Lockhart et al., 2009). Antibiotics have been widely used for chemotherapy, plant disease treatment, livestock drugs, biotechnology, and molecular biology (Smitha and Philip, 2014). The emergence of resistant strains impels the search and development of newer antibiotics, such as PBL (soft rot disease) in orchid flower stalks (Joko and Kusumandari, 2014) as well as leaf and neck blast in upland gogo rice (Nasution et al., 2014). Candida albicans as a pathogen in

\footnotetext{
*Corresponding author:

Sri Yuwantiningsih

Biotechnology, Study Program, The Graduate

School, Universitas Gadjah Mada
}

the human esophagus, vulva, and vaginal skin has been widely studied in order to discover new anti-fungal compounds (Mohammed et al., 2012), also Moler disease in onion leaf (Lestiyani et al., 2014) and rot disease in pineapple and mango by Fusarium sp. (Widiastuti et al., 2014). In recent years, antibiotics have been studied and extracted primarily from soil microbes. However, other sources, such as endophytic microbes, may also possess potential desirable traits. Endophytic microbes are compatible with a wide variation of host type and characteristics as well as various ecosystems, allowing them to be found in diverse species. Under different environmental conditions inside plant tissues, endophytic microbes may produce antibiotics with higher bio-activity than those from microbes originating from soil or plant surfaces (Strobel et al., 2004; He, 2009). 
Yuwantiningsih et al.

Endophytic bacteria live inside plant tissues without endangering the host. Instead, the bioactive compounds produced by the endophytic bacteria control possible invading pathogens (Patel et al., 2012). Endophytic bacteria live mutualistically with various plants in different environmental conditions and that provide a wide range of endophytic bacteria biodiversity with different potential bioactive compounds.

Bioactive compounds with high bioactivity can be found from microbes in plants in tropical rain forests in specific regions, and have long been used as a local medicine (Strobel et al., 2004). Research shows that isolates from some national parks in the Indonesian islands of Sumatra, Java, and Bali have a high effectiveness against several plant pathogenic bacteria (Meliawati et al., 2006). Margino (2008) also reported that isolates derived from rare plants in Yogyakarta, Java, were indicated to have anti-fungal trait. Isolates from Taman Negara National Park in Pahang, Malaysia, have also been known to produce compounds with potent cytotoxic and antibacterial properties (Hazalin et al., 2009), as well as surfactant for Fusarium sp. growth inhibiton (Snook et al., 2009).

Previous studies have been conducted to obtain and select endophytic bacteria isolates from selected plants taken from a Javanese National Park. The result of the study was three selected superior isolates, namely OOH-1, STG-1, and CMB-2. As a continuation of the previous study, this research was conducted to determine the molecular identity of OOH-1 and STG-1 isolates, as well as the identification of antibiotic compounds produced by STG-1 as a model isolate for lab. scale production because of its largest inhibition zone against Fusarium oxysporum.

\section{Materials And Methods \\ Tools and Materials}

The tools used in this study were: Autoclave, Oven, Centrifuge $4^{\circ} \mathrm{C}$ (Beckman
I.J. Biotech, Vol. 20, No. 2

J), Microcentrifuge (Beckman microfuge II), PH meter 691 (Metrohm), electrophoresis cell (Bio-Rad Mini-Sub ${ }^{\circledR}$ TM DNA cell), PCR (Mastercycler personal, Eppendorf), Sequencer ABI PRISM (310Genetic Analyzer). The materials used in this research were: OOH-1 and STG-1 isolates, Ready-To-Go PCR kits, DNA marker (1KB DNA Ladder, Promega), Primer 27F and 1492R (SBS Genetetech Co., Ltd.), DNA purification kit (Microclean Microzone Ltd.), and silica gel $60 \mathrm{G} \mathrm{F}_{254}$.

\section{Molecular Identification}

Some numbers of endophytic bacteria were isolated from plants in Ujung Kulon, Kaliurang, Meru Betiri and Baluran National Park, Bogor Botanical Garden, and Nusakambangan forest, Indonesia in previous study. Selected superior isolates, namely OOH-1, STG-1 were used for DNA isolation. Isolation of bacterial chromosomal DNA was done using a method developed by Pospieech and Neumann (1995). $16 S$ rRNA gene amplification was performed with primers $27 \mathrm{~F}$ and $1492 \mathrm{R}$ with an initial denaturation PCR condition of $94^{\circ} \mathrm{C}$ for 2 min, followed by 40 cycles of $94^{\circ} \mathrm{C}$ for 30 seconds, $51^{\circ} \mathrm{C}$ for 30 seconds, and $72^{\circ} \mathrm{C}$ for $1 \mathrm{~min}$, and a cycle of $72^{\circ} \mathrm{C}$ for 10 minutes. The PCR products were confirmed using electrophoresis on $2 \%$ agarose gel.

Visualization was done under UV light (Song et al., 2009). 16S rRNA PCR products were subsequently sequenced with the procedure according to the manual procedures used by the DNA sequencer and then analyzed using the BLAST-N program on the NCBI page (https:/ / www. ncbi.nlm.nih.gov/blast/). A phylogeny tree was constructed by comparing the sequences of the obtained $16 \mathrm{~S}$ rRNA bacterial isolates with sequences from the Gen Bank database (https://www.ncbi. nlm.nih.gov/genbank/). The phylogeny tree was constructed using the MEGA program version 6 . 
Yuwantiningsih et al.

\section{Purification and Separation of Antibiotic Compounds}

Antibiotic compounds were identified initially using thin layer chromatography (TLC). Selected endophytic bacteria were inoculated on each respective media in accordance with previous methods. A $500 \mathrm{ml}$ Erlenmeyer flask filled with $150 \mathrm{ml}$ media was incubated in a shaker at $150 \mathrm{rpm}$ for 4 days at a temperature of $30-33^{\circ} \mathrm{c}$. The sample was centrifuged to separate the supernatant and pellets, and then purified further using TLC. The sample was centrifuged with the addition of a mixture of ethyl acetate and butanol, until the supernatant and pellets were separated. The supernatant was then taken, while the pellets with the ethyl acetate and butanol mixture were centrifuged repeatedly until clear.

The obtained fractions were then dissolved in a solution of chloroform:methanol (1:1) and put on a preparative plate, then processed into separation with a stationary phase of silica gel $60 \mathrm{f}$ and $254 \mathrm{f}$ and eluted with mobile phase of n-hexane:ethyl acetate (93:7). After the elution was finished, the results were observed under visible light and then scraped off. The resulting extract was dissolved with n-hexane:ethyl acetate (93:7) and packed on sintered glass. The eluate were evacuated and evaporated at room temperature. The powder obtained was then used in the following analysis.

\section{LC $_{50}$ Test Against Fusarium oxysporum}

Antibiotic activity was also examined for its Lethal Concentration $\left(\mathrm{LC}_{50}\right)$ against Fusarium oxysporum by examining colonies formed while under the stress of the added compound (Tebbets et al., 2013). The microbe culture indicator, Fusarium oxysporum, was cultivated in PDA media. As much as $10 \mathrm{ml}$ of cell culture was added into petri dishes containing the media, and added with various antibiotic compound concentrations of $0,50,100,200,300$, and $500 \mathrm{mg} / \mathrm{ml}$.
I.J. Biotech, Vol. 20, No. 2

\section{Results and Discussion \\ Molecular Identification}

The identification of two strains of endophytic bacteria that produce antibiotic compounds, namely STG-1 and OOH1 isolates was performed based on $16 S$ rRNA gene analysis via polymerase chain reaction using the universal $27 \mathrm{~F}$ primer (AGAGTTTGATCMTGGCTCAG) and 1492R Primer (TACGGYTACCTTGTTACGACTT). Then the reaction was checked using gel electrophoresis. There was only a single band on the outcome of PCR in a measure about $1500 \mathrm{bp}$ indicating that it was a $16 \mathrm{~S}$ band.

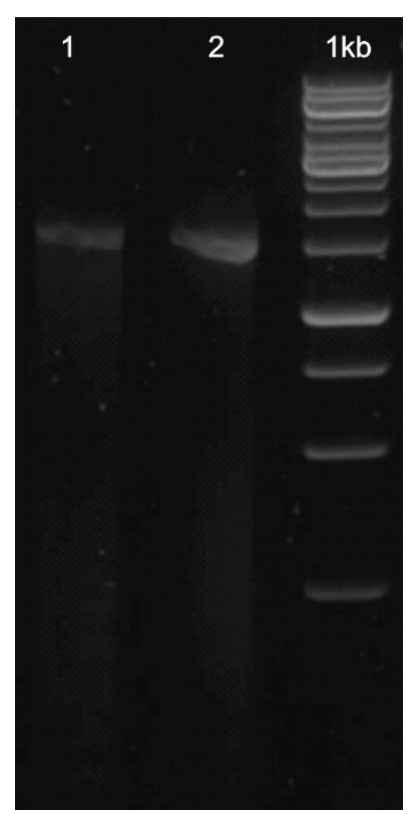

Fig 1. Gel electrophoresis on the outcome of PCR STG-1 (1) and OOH-1 (2).

The molecular identification of STG-1 and OOH-1 isolates was based on $16 \mathrm{~S}$ rRNA sequence analysis. The DNA sequences obtained were further used to investigate the identity of the bacterial isolates using the BLAST-N program (Basic Local Alignment Search Tool-Nucleotides). Based on the highest BLAST similarity, 
Yuwantiningsih et al.

I.J. Biotech, Vol. 20, No. 2

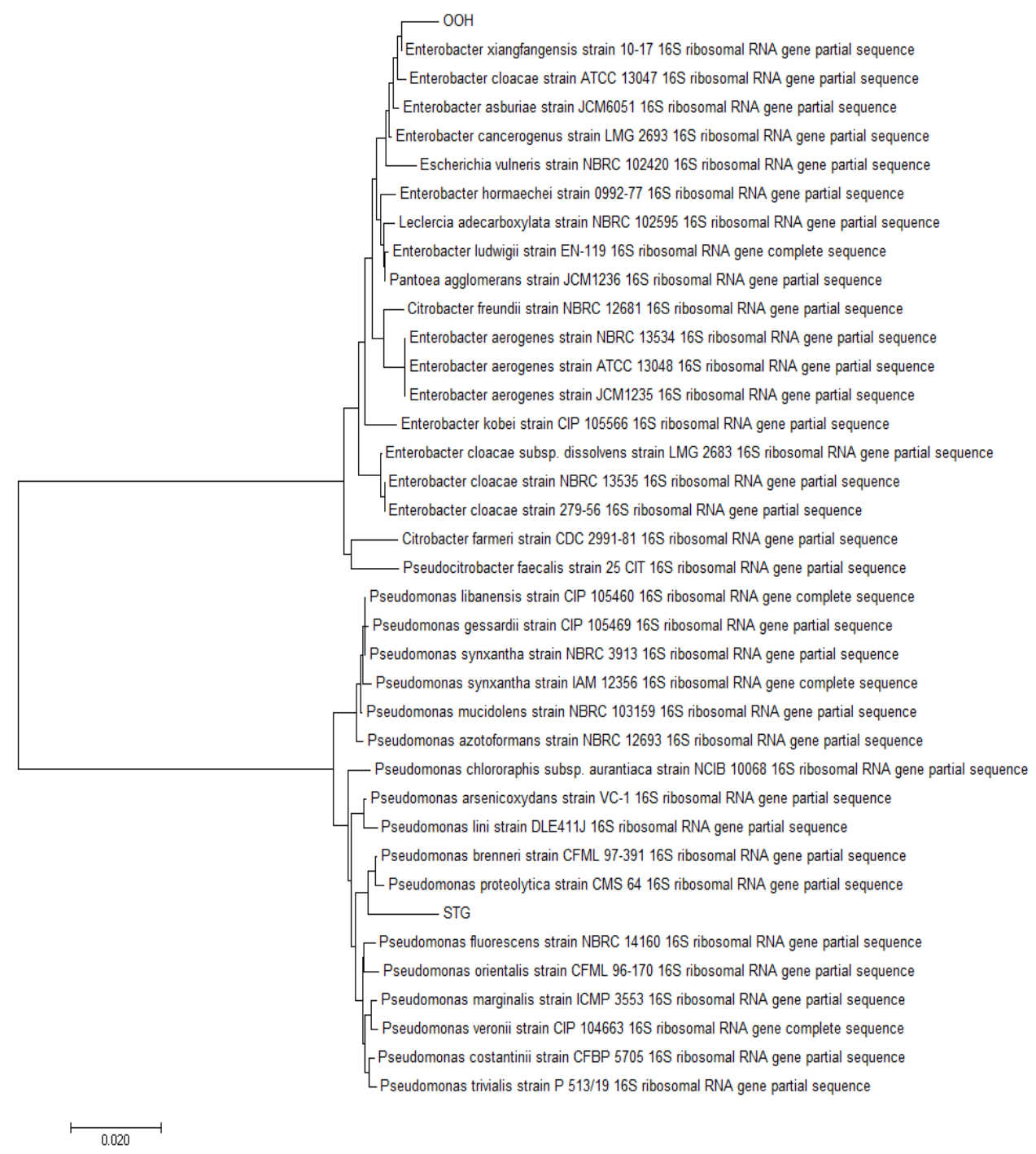

Fig 2. Phylogenetic tree based on $16 \mathrm{~S}$ rRNA gene sequences of Pseudomonas and Enterobacter bacteria isolate groups.

each isolate was assigned a species name. The results are summarized in Table 1. Janda and Abbott (2004) reported that the identity of a bacterial strain is the same if it has a similarity value with the type strain of bacteria at least $99 \%$.

These sequences were compared with previously published sequences of two bacterial groups. Group 1 consisted of Pseudomonas migulae strain CIP 105 470, Pseudomonas panacis strain C62010 and Pseudomonas proteolitica strain CMS 64, Pseudomonas brenneri strain CFML 97391, Pseudomonas synxantha strain NBRC
Table 1. Results of the analysis of $16 \mathrm{~S}$ rRNA gene sequences using the BLAST-N program.

\begin{tabular}{|c|c|c|c|}
\hline $\begin{array}{c}\text { Isolates } \\
\text { code }\end{array}$ & $\begin{array}{c}\text { Homolog Bacteria } \\
\text { Species }\end{array}$ & $\begin{array}{c}\text { Access } \\
\text { Number }\end{array}$ & $\begin{array}{c}\text { Similarity } \\
(\%)\end{array}$ \\
\hline STG-1 & $\begin{array}{c}\text { Pseudomonas } \\
\text { brenneri strain } \\
\text { CFML 97-391 }\end{array}$ & NR.126208.1 & 99 \\
\hline $\mathrm{OOH}-1$ & $\begin{array}{c}\text { Enterobacterxiang } \\
\text { fangensis strain } \\
10-17\end{array}$ & NR.025103.1 & 99 \\
\hline
\end{tabular}

3913. Group 2 consisted of Enterobacter xiangfangensis strain 10-17, Enterobacter hormaecie strain 0992-77 and Enterobacter cloacae strain ARCC 13047. The results of 
Yuwantiningsih et al.

sequence comparisons are visualized in a phylogenetic tree (Fig 2).

STG-1 isolate was in one group with Pseudomonas brenneri strain CFML 97-391 and Pseudomonas proteolytica strain CMS 64, whereas $\mathrm{OOH}-1$ isolate was in one group with Enterobacter xiangfangensis strain 1017. Therefore, STG-1 is closely related to Pseudomonas brenneri strain CFML 97-391 and $\mathrm{OOH}-1$ is closely related to Enterobacter xiangfangensis strain 10-17.

\section{Purification and Separation of Antibiotic Compounds}

The identification of antibiotic compounds was performed only on STG-1 as a production model isolate, which was based on the nature and specific reagents that can be detected by fractionation of phytochemicals and thin layer chromatography (TLC).

Antibiotics produced by STG-1 had an $\mathrm{Rf}$ value of 0.82 after elution with $\mathrm{NH}_{4} \mathrm{Cl}$ and $\mathrm{Rf}$ value of 0.90 on eluent water that was saturated with butanol. To obtain the antibiotics, these eluent can be used based on the observed spot, which is the purple colored spot beside the standard solution of stigmasterol. The compound was then

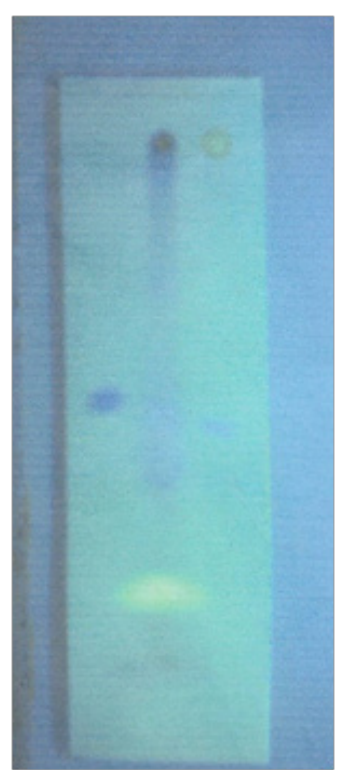

Fig 3.The results of the analysis of antibiotic compound from isolate STG-1 spot under visible light.
I.J. Biotech, Vol. 20, No. 2

found belong to a group of steroids. The eluate was dissolved with a solvent mixture of chloroform:methanol (1:1) and incubated between 15-20 minutes to saturate and provide a bridge to enable the selection of active compounds and their derivatives into the chloroform phase. This study also aimed to reduce the number of components to be fractionated (El Shohly et al., 1999).

The fractions were then spotted on the preparative plate and eluted with the mobile phase consisting of n-hexane:ethyl acetate (93:7). The elution results were seen under visible light and the yellow spots were found. The results of subsequent fractionation poured in sintered glass and the eluate was evaporated in an evaporator (Rinanto et al., 2008).

\section{Activity Analysis of Antibiotics with Lethal Concentration ( $\mathrm{LC}_{50}$ )}

The $\mathrm{LC}_{50}$ of antibiotic compounds in various concentrations was determined according to Tebbets et al. (2013). With a little modification, the determination of the concentration of antibiotics performed through some dilution concentrations, namely $10^{-1}, 10^{-2}, 10^{-3}, 10^{-4}, 10^{-5}$, and $10^{-6}$. The microbial indicator, Fusarium oxysporum, was grown on PDA media for 48 hours. Cultures were mixed with various antibiotic concentrations, grown on agar medium using the pour plate method, and the observations were made after 24 hours. The results showed that the concentration that kills half of the microbial indicator ranged from 100-200 $\mu \mathrm{g}$ / $\mathrm{ml}$ to $273 \mu \mathrm{g} / \mathrm{ml}$ (Fig 4).

Based on the study of antibiotics toxicity from endophytic microbe was known that amphoterisin-B and voriconazole with Fusarium oxysporum and $\mathrm{LC}_{50}$ was 250 $\mu \mathrm{g} / \mathrm{ml}$ (Wiyakrrutta et al., 2004), whereas fluconazole was $64 \mu \mathrm{g} / \mathrm{ml}$ and mancozeb with phenylmercury acetate was effective to kill Fusarium oxysporum pathogen. The results were compatible with other finding that the toxicity of antibiotics isolates from STG -1 can be used as a reference in determining new antibiotics with similar compounds. 


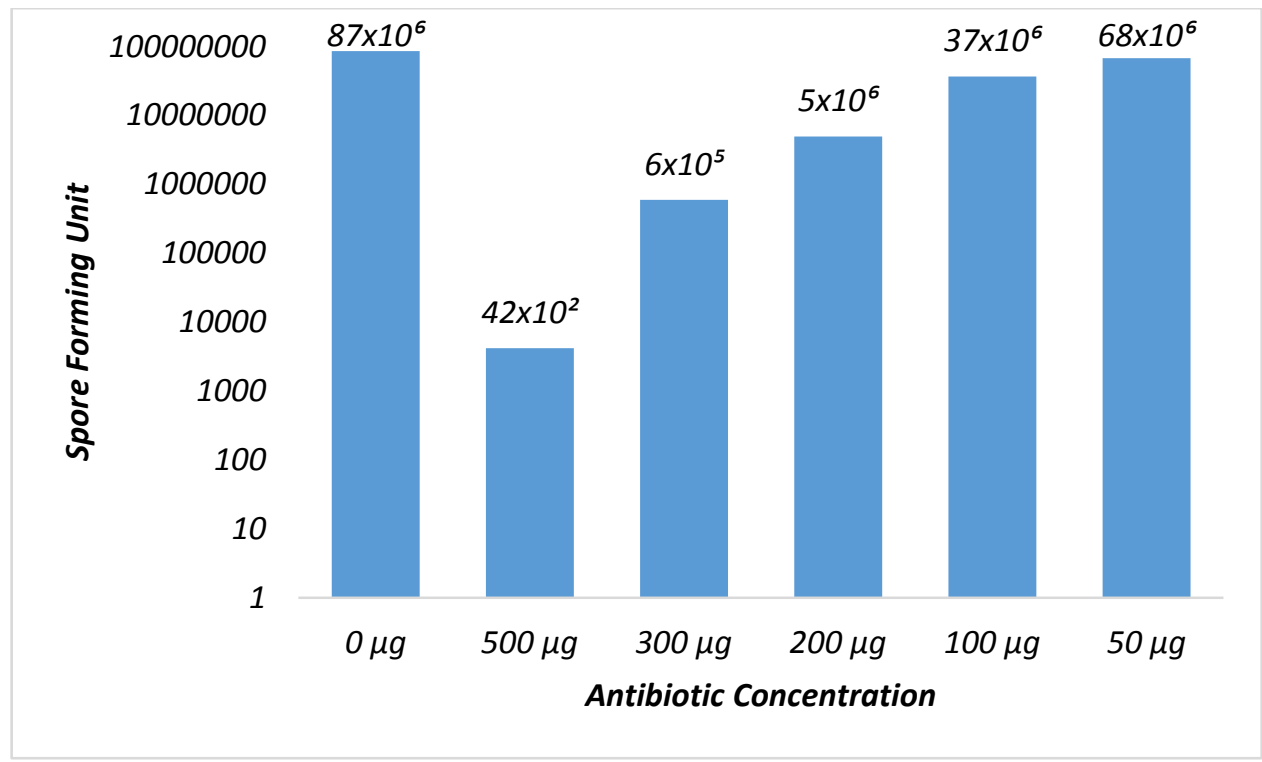

Fig 4.Effect of the antibiotic concentration on the growth of Fusarium oxysporum.

The results on antibiotic compound production of the Pseudomonas genus as well as Pseudomonas viridiflava endophytyc bacteria showed that the antibiotic compounds contained surfactin agents that could act as biocontrol agents of Fusarium oxysporum, were highly biodegradable and had low toxicity (Snook et al.,2004). This antibiotic compound was identified as the major lipopeptida for the toxic component. The antibiotic activity is accomplished on concentration dependent actvity, low concentrations, and its product comformational changes within the phospolipids. At intermediate concentrations, it causes segregation within the bilayers, resulting in channels that are permeable to cations. At high concentrations, it produces a detergent effect resulting in complete membrane disruption. The results of this study revealed that Pseodomonas brenneri produced a steroid antibiotic compound against the pathogenic fungus Fusarium oxysporum.

\section{Conclusion}

The results of molecular identification showed that isolate STG-1 had a 99\% level of similarity with Pseudomonas brenneri strain CFML 97-391 and isolate $\mathrm{OOH}-1$ had a $99 \%$ level of similarity with Enterobacter xiangfangensis strain 10-17. The results of this study showed that STG-1 isolate produced antibiotic compounds belong to steroid group and had an $\mathrm{LC}_{50}$ of $0.01-0.02 \%$ against the microbial indicator of Fusarium oxysporum.

\section{References}

Bicchi, C.and Rubiolo, P. 1996. High performance liquid chromatographic particle mass spectrometri analysis of sesquiterpeneLacton with different carbon sceletons. Journal of Chromatography 727: 211-221.

El Sohly, H. N., Croom, E.M., El Feraly, F.S. and El Sherey M.M. 1990. A Large-scale extraction technique of artemisin from Artemesiaonnua. Journal of Nat. Prod. 53(6):1560-1565.

Joko T. and Kusumandari N. 2014. Deteksi molekuler bakteri penyebab penyakit busuk lunak pada anggrek menggunakan teknik Polymerase Chain Reaction. Pengembangan dan pemanfaatan IPTEKS untuk kedaulatan pangan. Seminar Nasional Dies Natalis Faperta UGM ke-6 Jong de and Claessen, D. 2014, A sandwichculture technique for controlling antibiotik production and morphological 
Yuwantiningsih et al.

development in Streptomyces coelicolor. Journal of Microbiological Methods. 10: 10-16.

He, R.I., Wang, G.P., Liu, X.H., Zhang, C.L and Lin.F.C. 2009. Antagonistic bioactivity of an endophytic bacterium isolated from Epimedium brevicornu Maxim African Journal of Biotecnology. 8(2): 191-195.

Lestiyani, A., Wibowo, A., Subandiyah, S. 2014. Uji metode inokulasi pada bawang merah dengan Fusarium spp. Pengembangan dan Pemanfaatan IPTEKS untuk Kedaulatan Pangan. Seminar Nasional Dies Natalis Faperta UGM ke-68.

Lockhart, S.L., Kiederma, D.J., Pfaller, M.A. 2009. The Epidemiology of Fungal Infection InAnaissie, EJ, McGinnis MR, Pfaller MA. (eds). Of Clinical Mycologv. $2^{\text {nd }}$ ed oxford $V$ K ElseviSp Inc.

Margino, S. 2008. Produksi metabolit sekunder (antibiotik) oleh jamur endofit. Majalah Farmasi Indonesia 19: 86-94

Meliawati, R., Widyaningrum, D.N., Djohan, A.C., Sukiman, H. 2006. Pengkajian bakteri endofit penghasil senyawa bioaktif untuk proteksi tanaman. Jurnal Biodiversitas. 7(3) :221-224.

Muhammed, M., Fuchs, 13. B., Wu, M.P., Breger. J., Coleman, J.J., Mylonakis, E. 2012. The role of mycelium production and a MAPK-mediatedimune response in the C. elegans - Fusarium model system. Journal of Medical Mycology. 50: 488-496.

Nasution, A., Usyati, N., and Santosa. 2014. Varietas lokal padi sebagai sumber ketahanan penyakit blas daun dan blas leher. Pengembangan dan pemanfaatan IPTEKS untuk kedaulatan pangan. Seminar Nasional Dies Natalis Faperta UGM ke-68.

Patel, H.A., Khristi, S.M., Perikh, K. and Rajeram G. 2012. Isolation and Characterization of Bacterial endophytic from Lycopersicumesculentum plant and their plant promoting characteristics. Nepal. Journal of Biotechnology 2(1): 37-52.

Rinanto, Y., Sumarni, T., Iskamto, B. 2008. Fraksi aktif jamur Candidaalbicans dar
I.J. Biotech, Vol. 20, No. 2

iekstrak metanalik bunga kamilen (Matricamachamommilla L.) Majalah Farrnasi Indonesia. 19 (2): 65-69.

Silverstein, R.M., Bassler, G.C. and Morrill, T.C. 1991. Spectometric identification organic compounds. Fifth Edition. John Willey and Sons Inc. Singapore 1-410.

Smitha, S.L. and Philip, R.K. 2014. Antibiotik Organic Compound production by a marine fungus Pencilliumcirinum S36 through solid state fermentation: optimization by response surface methodology. International Journal of Research Biomedicine and Biotechnology 4(1): 6-13.

Snook, M.E., Mitchel, T. Hinton D.M. and Bacon, C.W. 2009. Isolation and characterization of leu7-surfactin from the endophytic bacterium Bacillus mojavensis RRC 101, a biocontrol agent for Fusarium verticillioides. Journal of Agriculture and Food Chemical. 57: 4287-4292.

Song, I., Ye.C., Zhang, Z., Lu, Y. and Ind Jing, K. 2014. Daptomycin antibiotic production processes in fed-batch fermentation by Streptomyces roseosporus NRRL. 11379 with precusor effect and medium optimization. Journal of Bioprocess Biosynthesis Enginering (37): 415-423

Strobel, G., Daisy, B., Castillo, U. and Harper J. 2004. Natural Product from Microorganism. Journal of Natural Product. 67: 257-269.

Tebbets, B., Yu, Z., Stewart, D., Zhao, L.X., Jiang, Y.I., Qu, L.H., Andes, D., Shen, B. and Klein, B. 2013. Identification of antitungal natural products via Saccharomyces cerevisiaebioassay : insight in to macrotetrolide drug spektrum, potency and mode of action. Journal of Medical Mycolou. 51: 280-289.

Widiastuti, A. and Ningtyas, O.H. 2014. Identifikasi jenis jamur penyebab busuk pada beberapa buah pasca panen di Yogyakarta. Pengembangan dan pemanfaatan IPTEKS untuk kedaulatan pangan. Seminar Nasional Dies Natalis Faperta UGM ke-68. 